\title{
Euricse
}

European Research Institute

on Cooperative and Social Enterprises

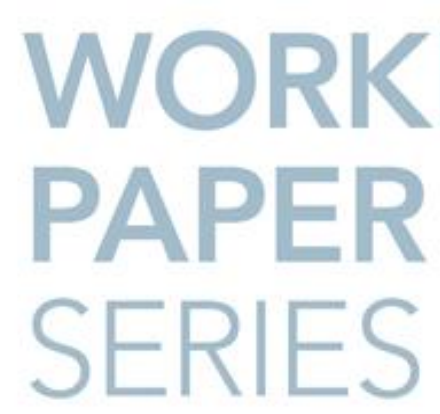

ISSN 2281-8235 Working Paper n. 90|17 Ermanno Tortia

\section{The Firm as a Common. The Case of the Accumulation and Use of Capital Resources in Co-operative Enterprises}

Please cite this paper as:

Tortia, E.C. (2017), The Firm as a Common. The Case of the Accumulation and Use of Capital Resources in Co-operative Enterprises, Euricse Working Papers, 90|17. 


\title{
The Firm as a Common. The Case of the Accumulation and Use of Capital Resources in Co-operative Enterprises $^{1}$
}

\author{
Ermanno C. Tortia ${ }^{2}$
}

\begin{abstract}
Contemporary literature dealing with the governance of the exploitation of common-pool natural resources was initiated by Elinor Ostrom in 1990, and has been growing fast ever since. On the contrary, within the same research stream, the study of the presence and economic role of common resources in entrepreneurial-organizational is, to date, under-researched. This work endeavours some attempt to fill this gap. Firstly, by spelling out a new-institutionalist framework for the analysis of the accumulation and governance of common capital resources within organizational boundaries. Secondly, by considering co-operative enterprises as the organizational form that, on the basis of historical record, and of behavioural and institutional characteristics, demonstrated to be most compatible with a substantial role for common and non-divided asset-ownership and with its governance thereof. The economic forces influencing the optimal level of self-financed common capital resources in co-operatives are enquired. Also their governance is brought under the spotlight, evidencing: (i) the constraints that need to be fulfilled, and the potential benefits arising out of their presence; (ii) the compatibility and mutual adaptability between democratic governance in cooperatives and the governance of non-divided assets.
\end{abstract}

\section{Key words}

Co-operative enterprises; Indivisible reserves; Common resources; Rivalry; Non-excludability; Capital accumulation; Governance.

\section{JEL classification codes}

\section{P13, P14, P48, P51}

\section{Acknowledgements}

This paper is part of the output of the research project "The use of common resources in co-operative firms. A comparative inquire in Scotland and the Trentino Province", funded in 2010 by the Autonomous Province of Trento under the Seventh Framework Programme "People" - "Marie Curie Actions" - COFUND Researcher Outgoing 2010. The author thanks the funding body and counsel; Ugo Pagano for discussing the paper during the $10^{\text {th }}$ Annual Conference of the Italian Association for Law and Economics (SIDE - ISLE) held in 2011 in Turin; Luigi Bonatti, Carlo Borzaga, Johnston Birchall, Giacomo Degli Antoni, Elinor Ostrom, Lorenzo Sacconi and Richard Simmons for valuable comments on the Discussion Paper no. 12/2011) of the Department of Economics, University of Trento: "The firm as a common. The case of accumulation and use of common resources in mutual benefit organizations"; Anthony Jensen and Cecilia Navarra for their comments during the workshop "Advancing the Co-operative Movement in Australia and Italy" held in July 2011 at the University of Trento and Euricse (European Research Institute on Co-operative and Social Enterprises, Trento). Usual disclaimers apply.

\footnotetext{
${ }^{1}$ An earlier version of this paper in Italian language was published in L. Sacconi and S. Ottone (Eds.) (2015), Beni comuni e cooperazione, Bologna, Il Mulino.

${ }^{2}$ University of Trento, Department of Economics and Management and Euricse, Email: ermanno.tortia@unitn.it
} 


\section{Introduction}

Following the growing evidence on the necessity to accomplish environmentally sustainable economic development, the study of the governance and exploitation of natural resources gained prominent role in economics and the social sciences, ever since the seminal contribution by Elinor Ostrom in 1990 (Ostrom, 2007; Frischmann, 2013; Hodgson, 2013; Pennington, 2013; Cole, Epstein and Mcginnis, 2014). Common goods are subtractible, hence characterized by high degree of rivalry in consumption and/or utilization, but by a low degree of excludability for subjects entitled to the exploitation of the good. They appear as private good to outsiders, but are common goods for insiders. Common-pool natural resources (CPRs) are studied to highlight the necessity to limit exploitation of fringe and flow resources to a level that does not damage the productive potential of the stock, or core resource. Institutional mechanisms identified in rules regulating access and management are needed to enforce appropriation rights and their limits (Ostrom and Basurto, 2011). This research stream came to concentrate on self-managed common property regimes, which cannot be simply equated either to public or to private ownership, but share some features of both, and have been highlighted as the most typical way in which natural resources are managed and exploited (Ostrom, 1990). More recent literature concentrated on forms of communitarian ownership generating positive externalities as concern knowledge/cultural commons (Frischmann, 2013), and urban spaces (Sacchetti and Campbell, 2014; Sacconi and Ottone, 2015).

Mechanisms governing the use and exploitation of common resources and the resolution of conflict thereof have been studied to overcome tragedy of the commons situations, as in Hardin (1968). Given the rival and non-excludable nature of such resources, conflict over their appropriation and overexploitation are to be considered endemic. The technology used and the governance structure are functional to adequately regulating appropriation, by limiting the risk of conflict and by punishing the violation of appropriation and working rules (Ostrom, 2010; Ratner et al., 2010). Governance, besides limiting the risk of opportunism by the involved parties, is also functional to the coordination of collective action (Lopes, Santos and Teles, 2009). Adequate coordination can be achieved not only by controlling and punishing defectors, but also through proper involvement and deliberation processes based on membership rights and other consultative and participative practices, which can allow and add value to improved information circulation, and the creation of new specific knowledge and organizational trust (Meinzen-Dick, Mwangi and Dohrn, 2006; Poteete, Janssen and Ostrom, 2010).

The analysis of the governance of common resources has been applied to the entrepreneurial and organizational realms only to a notably limited extent. Some streams of literature in law and economics did start this field of enquiry, by defining business corporations as a form of "team production" (Blair and Stout, 1999) and by enlarging the concept of corporate governance to include a wide array of mechanisms mitigating risk and uncertainty in contractual relations (Deakin and Hughes, 1999), and to represent the multi-stakeholder corporate embodiment of the social contract (Sacconi, 2004). Some authors got to identify corporate dimensions that can be likened to common goods, and business enterprises have been explicitly understood as "commons" themselves (Deakin, 2012; Sacconi and Ottone, 2015). However, to the best of the author's knowledge, no contribution 
has systematically analysed the corporate patrimony within the common-pool resources framework, and explicitly discussed in this line the specific features of "alternative" or "heterodox" enterprise forms, such as co-operatives, social enterprises, and entrepreneurial non-profit organizations (Lichtenstein, 1986), exception made for few contributions, such as Navarra (2011) on capital resources in worker co-operatives and by Perilleux (2017) on co-operative finance. This work is directed to widen the literature evidencing the analogies between business corporations and their patrimony with common goods, to study the features and economic functions of common-pool capital resources and to evidence the specificities of co-operative enterprises as organizational form suited to accumulate common-pool capital resources.

One initial key question in this study concerns the reasons why such analysis is largely absent in contemporary economics and management literatures. The proposed answer concerns the dominant system of property rights, whose concentration and exclusivity limits the economic and managerial relevance of communality in the ownership of enterprises ${ }^{3}$.

This work concentrates on common resources understood as non-divided and non-divisible ownership of capital assets in firms. The accumulation of owned capital is observed in all entrepreneurial forms, since it is needed to finance investment programs, to buffer the organization against negative unpredicted events, and to serve as collateral guarantee in favour of external finance. Capital resources can be characterized by a positive degree of communality in all ownership forms (public, private and co-operative) when the relevant operative and strategic decisions are taken by a collectivity of controlling patrons (the resource cannot be easily made excludable) and the "exit" option is costly. The utilization of a limited and rival stock of assets coupled with a low degree of excludability in decision making can engender a "tragedy of the commons situation" characterized by free riding in contribution and over-exploitation. In this field of enquire, co-operative enterprises are identified as privileged organizational contexts since, both in their historical origin and institutional evolution, they have been characterized in most countries by the presence of capital resources that are non-divided and non-divisible among their members.

The strategy of the paper is as follows: Section 2 deals with the definition, economic relevance, pattern of emergence and optimal dimension of non-divided capital funds in both investor owned companies and co-operative enterprises. The origin and spread of common capital resources in cooperatives is analysed within a new institutionalist frame by comparing their costs and benefits, both transactional and productive, with the costs and benefits of individually held capital resources. Section 3 studies the consequences of the spread of common capital resources for the governance structure and self-directed production of working rules in co-operatives. Critical elements and positive potential of co-operative governance are analysed. Section 4 concludes.

${ }^{3}$ Since priority is given to the analysis of the private sector, only investor owned companies and co-operative enterprises are considered in this paper. Occasional references to publicly owned organizations may solely have an exemplifying role. 


\section{Common resources in investor owned and in co-operative enterprises}

The diversity of organizational forms in terms of control rights can induce important differences in the analysis of the presence and modalities of utilization of common resources. The paper briefly considers investor owned companies (IOFs hereafter) first, and then introduces the case of cooperative enterprises.

\subsection{Common capital resources in investor owned companies}

The strictly private nature of capital resources in IOFs strongly reduces as a norm, and often eliminates the relevance communality, since shares are saleable and, in most cases, ownership is concentrated in a few hands. Decision making becomes exclusive, and excludability in utilization is perfect after contractual constraints have been fulfilled (Sacchetti, 2013). This is the standard observed solution in small to medium sized firms, and in family businesses, which are numerically dominant in all contemporary economies.

However, even in the case of IOFs, capital resources can acquire a relevant degree of communality when the firm is constituted as joint stock. More specifically, as the number of stockholders increases, and no stockholder achieves dominant position (ownership is dispersed), costly exit due to sunkness of capital resources and investments and to asset specificity can induce a high degree of rivalry in the utilization of resources and in the appropriation of the surplus. In the same situation, nonexcludability in decision making, in the utilization of assets, and in the distribution of value added is likely to be high as well ${ }^{4}$.

As said, a high degree of rivalry and non-excludability is to be considered, in IOFs, as exception, not as the rule, due to concentrated ownership. Furthermore, even in the presence of a high degree of nonexcludability in decision making and capital utilization, the "exit" option represented by the sale of stocks can allow stockholders to recoup the value of their financial investments. In other words, the sale of owned stocks can be the preferred choice whenever non-excludability in decision making leads to a "tragedy of the commons" situation in which individual objectives conflict with collectively optimal choices, and organizational costs are inflated by the growth of decision making costs. Conversely, stockholders may in many situations prefer concentrated to dispersed ownership since the former solution allows for the elimination of inefficient and costly collective choices when asset specific and non-recoupable investments make the exit option costly. These remarks can explain the prevalence of concentrated ownership in IOFs in most contemporary economies. At the other extreme of the spectrum, sole-proprietorship or closely-held joint-stock are found ${ }^{5}$.

\footnotetext{
${ }^{4}$ This argument is ever more valid in widely held joint-stock and in publicly quoted companies characterized by fragmented shareholdership in which no dominant position is detected. However, in these companies, the emergent dominant role of the management due to separation between ownership and control can reduce the problems related to communality thanks to centralized decision making (Berle and Means, 1932). The same result would not be possible in co-operatives since, in their case, managers are appointed by members' representatives, and need to respond more closely to their preferences (Hansmann, 1999). In this case, communality and the connected behavioural biases such as freeriding can represent a more serious challenge.

${ }^{5}$ In an evolutionary interpretation, concentrated ownership can be considered a central autopoietic property of capitalism property rights (Valentinov, 2015).
} 


\subsection{Common capital resources in co-operative firms}

Co-operative enterprises are here understood as mutual benefit organizations characterised by membership rights that are not based on financial investments, but instead set up on the basis of the "one member, one vote" rule (Birchall, 2010; Borzaga and Tortia, 2017). Indivisible or common reserves of capital in co-operatives, when they are present, are owned by the organization itself and cannot be shared among individual members, who enjoy a form of usufruct of the assets, but cannot appropriate them. ${ }^{6}$ The accumulation of indivisible reserves, or asset lock, has the primary function to self-finance investment programs, to create collateral guarantees protecting external financial supporters, and to insure the membership against negative unpredicted events (Tortia, 2007; Navarra, 2011). Democratic and participative governance in the presence of non-divisible, hence not excludable, but scarce and subtractible capital resources engenders social dilemmas that are typical of the utilization of common resources: conflicting objectives in collective decision making can entail substantial governance costs. Costs depend both on rivalry (alternative uses and appropriation of proceedings patterns may not be mutually compatible, and there can be overexploitation of limited resources) and of non-excludability (since all members have the legal right to participate on an equal basis, collective decision making can become complex, lengthy and contested, while conflict over the appropriation of the surplus can become endemic).

\subsubsection{Legal constraints}

Three main institutional models for the accumulation of capital resources in co-operative enterprises are singled out in western economies. In the first model, which mainly lies within the common law tradition, reserves of capital are, as a norm, divisible among members. Forms of common ownership are not mandated and, in some cases, excluded by law. They may be allowed when spontaneously created by individual organizations, and included in their bylaws. If we take the United Kingdom as the most relevant example in this kind of institutional tradition, we notice that, until recent years, bona-fide co-operative societies registered under the 1965 Industrial and Provident Act where not allowed to accumulate common or indivisible reserves. The possibility to introduce restrictions to divisibility of capital in companies' bylaws was introduced in the reformed 2002 Industrial and Provident Act and in the Co-operative and Community Benefit Societies Act in 2003. However, at the present stage of legislative development, the possibility for co-operatives to introduce a fully-blown asset lock is still barred by law, while it is allowed in community benefit societies since 2006 (Euricse, $2010)^{7}$.

The second and the third models are, instead, mainly found within the civil law tradition of continental Europe. In the second model, which includes France and Spain as national cases, the creation of indivisible reserves of capital that cannot be shared by members during the life of the organization is

${ }^{6}$ In some national systems, however, members can appropriate the residual value of the organization upon its liquidation or conversion.

${ }^{7}$ The asset lock regulation for community benefit industrial and provident societies has been in force and available for use since 2006 (The Community Benefit Societies Restriction on Use of Assets Regulations 2006/264). They implement the provisions of the 2003 Act to "lock in" the value of the assets and resources of a community benefit society. (cfr. : http://www.thenews.coop/32865/news/banking-and-insurance/uk-co-op-law-2010-summary/ ). 
mandated by law, but such reserves can be appropriated upon dissolution, sale, or conversion of the enterprise. In the third model, which is found mainly in Finland and Italy, compulsory accumulation of net residuals into indivisible reserves is coupled by the prohibition for members to cash in the residual value of the organization also upon its dissolution, sale, or conversion. The two civil law models share similarities, but also important differences. The former is characterized, comparatively, by stronger financial incentives, since members can appropriate the residual value of the organization. However, at the same time, the patrimony is less stable since divisibility in case of dissolution or conversion can represent, itself, an incentive to stop operation and cash in any residuls value (Pérotin, 2013). Conversely, the latter model can suffer from too weak financial incentives, as evidenced in the undercapitalization hypotheses by Furubotn and Pejovich (1970), and Vanek (1977), but, at the same time, has been showing a high degree of patrimonial stability since it does not offer incentives to demutualize or shut down operations. In both civil law systems, however, net operating losses can be imputed to indivisible reserves. This possibility can, in principle, weaken patrimonial stability since it is liable to mismanagement and unlawful appropriation. ${ }^{8}$ Finally, in the US context, a similar legal categorization exists, though in this case the main divide is drawn between co-operatives and nonprofit organizations. Only the latter are characterized by capital indivisibility, even if legislation does not forbid to mutual benefit organizations to impose indivisibility (Hansmann, 2001).

\subsubsection{Divisible and indivisible reserves of capital}

This section introduces a new-institutionalist account of the process of formation and of the economic motivations leading to the accumulation of non-divided forms of capital ownership in co-operatives. Building on the framework developed by Hansmann (1988, 1996, 1999, 2013), the basic category of transaction costs is considered and sorted into the two sub-categories of the net costs of (i) the governance of common resources, when they exist; (ii) individual ownership of the shares of capital of the co-operative. The costs attached to the two sub-categories are compared in order to single out the optimal level of common resources.

Co-operative enterprises can self-finance themselves in two fundamental ways: either by means of capital shares owned individually by members, or by resorting to non-divided and non-divisible reserves of capital, which take the form of the asset lock ${ }^{9}$. In the former case, individually owned financial instruments can have, and indeed have in different national contexts, pronouncedly different features, since they can be differentiated on the basis of yearly yields and reimbursement rights held by the member. Reimbursements rights can take different forms, since they can: (i) be perpetual and not refundable by the enterprise, albeit they may, under specific circumstances, be sold on the socalled market for membership rights (Dow, 1996, 2003), or pay annuities to incumbent members (Storey, Basterretxea and Salaman, 2014); (ii) be refunded when the member quits the organization; (iii) be refunded independently of the position as incumbent member under looser temporal

${ }^{8}$ The system of capital accumulation in the former Republic of Yugoslavia can be interpreted a radical version of the civil law system. Under Yugoslav self-management legislation all positive net residuals had to be reinvested in invisible reserves, whose function was to finance investments and absorb operating losses in the presence of a strict capital maintenance requirement, when prevented any reduction of the net book value of capital (Jossa and Cuomo, 1997).

${ }^{9}$ For the sake of simplicity, intermediate forms of common ownership in which indivisible reserves exist, but they can be appropriated by members upon closure or conversion of the c-operative are not considered. 
constraints (Dow, 1996, 2003; Ellerman, 1986). Finally, members can finance their organization also by subscribing firm loans or bonds.

Members' individual ownership of capital shares leads to capital variability whenever the shares need to be paid back to quitting or incumbent members (a situation common in most national systems of co-operative legislation); when shares are transformed into debt capital upon quittance of the member; and also when members can sell their shares on the market to non-members, since in these cases (refund, sale or transformation into debt capital) the total amount of owned capital is reduced. The intensity of capital variability is proportional to the percent of total capital individually held by members, and to members' turnover. Insofar as it can reduce and make uncertain the total dimension of the patrimony of the organization and its ability to constitute collateral guarantee for the firm's liabilities, variability can represent a limit to investment processes and to the ability of the organization to borrow on the market (Tortia, 2007; Pérotin, 2013). By constituting indivisible reserves, locked assets effectively counteract capital variability ${ }^{10}$.

A second function of non-divided ownership is found in the necessity to counteract the risk of demutualization, that is the termination of a co-operative through the sale of assets, or through conversion into a IOF. When the capital is individually owned, its variability coupled with members' turnover can lead to undercapitalization: the co-operative would have to refund or transform into bonds or loans a high share of owned capital, thus leading to increased dependence on external finance, higher leverage and lower collateral guarantees (Tortia, 2007; Pérotin, 2013). When this problem becomes severe, the co-operative can be forced to demutualize in order to increase owned capital (equity) and reduce leverage. Clearly, co-operative members individually owning large shares of capital can also decide to demutualize in order to cash in the value of their individual assets. This problem is especially severe in best and worst performing organizations: in the former case, high value added co-operatives are characterized by market value of individual shares that is substantially higher than their face value, and this difference can represent a powerful incentive to liquidate the market value and convert into a $\mathrm{IOF}^{11}$. In the latter case, the risk of demutualization can create financial incentives favouring demutualization itself. When the organization fares negative financial conditions, members may be induced to sell out individual shares or the whole enterprise to external investors to reduce expected financial losses, this way aggravating the firm crisis. These remarks evidence that individual ownership, though it can strengthen financial incentives, is likely to substantially increase the patrimonial instability.

${ }^{10}$ In Italy, all typologies of co-operative enterprises (worker, consumer, producer and user co-operatives) are required by law to reinvest at least $30 \%$ of their net residual earnings into indivisible reserves of capital, which cannot be shared among members both during the life of the organization, and also upon its dissolution or conversion. This constraint is increased to $70 \%$ in the case of co-operative banks. Any residual value is to be transferred to national or regional funds controlled by co-operative associations, which finance the start-up of new co-operative ventures. Empirical evidence shows, however, that a dominant proportion of Italian co-operatives reinvests close to $100 \%$ of net residuals into locked assets. That is, the legal requirement is not nearly binding. This evidence supports the idea of the existence of an endogenous process of formation of locked assets in co-operatives (Navarra, 2011). As term of comparison, the Mondragon group of co-operatives in the Basque country can be considered. In this case net residuals are partly distributed to incumbent members (about 70\%, though this percentage has been varying over the years), who are mandated to reinvest their individual shares of capital in the co-operative as long as they are members; while the remaining share of net residuals is reinvested into indivisible reserves (Ellerman, 1986; 2007; Tortia, 2007). Due to members withdrawing the shares when they quit or retire, the total amount of the group assets held in common funds is, to date, about 50\% (MCC, 2015).

11 This has been the reason for the disappearance of the well-known group of lumberjack plywood co-operatives in the US pacific North West: the high market value of members' individual shares of capital made the sale of these organizations to IOFs more convenient than the sale of individual shares to new incoming co-operators. 
Demutualization is more common just in those institutional contexts that require or favour members' individual ownership of capital, typically in common law countries (cfr. For example Battilani, Balnave and Patmore, 2015, on Australia). The limited number of co-operative enterprises in these countries can be partially explained not by the higher death rate, but by the lower rate of creation and conversion into IOFs (crf. Burdín, 2015, on the ability of co-operatives to survive, on average, longer than IOFs). To exemplify, one well-known demutualization wave of co-operatives, mutual insurance companies, building societies and credit unions took place in the United Kingdom during the '80ies and the early '90ies of last century. In continental Europe, instead, demutualization has been less often observed. The lower rate of conversion contributes to the stronger presence and impact of cooperatives on national economies, and this evidence can be easily correlated with the much larger diffusion of non-divided reserves of capital, which depends on the legally mandated (partial) reinvestment of net residuals into locked assets ${ }^{12}$.

While in civil law countries the accumulation of indivisible reserves is, as a norm, required by law, common law countries, for example the UK, are witnessing in recent years a new trend favouring the diffusion of non-divided forms of capital accumulation. Constraints on divisibility, reimbursement and sale of individual shares are often introduced in the bylaws of co-operatives, social enterprises and employee owned companies by conferring either part or the whole patrimony into locked assets or trust funds (Erdal, 2011; Sacchetti and Campbell, 2014). The spontaneous emergence of forms of common ownership in institutional contexts in which they are not mandated by law confirms their substantive economic relevance and the potential for wider diffusion.

The legally imposed accumulation of indivisible reserves showed to be effective in preventing demutualization, but has been repeatedly accused to lead to dynamically inefficient investment choices, implying under-investment and under-capitalization (Furubotn and Pejovich, 1970; Vanek, 1970, 1977; Jossa and Cuomo, 1997; Pérotin, 2013). Even if the empirical evidence is not completely univocal, the phenomenon of undercapitalization due to suboptimal reinvestment of net residuals into locked assets and to the limited access to financial markets due to the absence of tradable equity has been taken as fundamental explanation of self-selection of co-operatives into low capital intensive sectors and of the reduced rate of creation of new co-operative ventures (Bartlett et al., 1992; Bonin, Jones and Putterman, 1993; Podivinsky and Stewart, 2006; Burdín, 2015). However, the ability of at least some forms of co-operative enterprises in some specific sectors, for example producer, agricultural and consumer co-operatives, to survive and prosper in many countries, even when the assets of the organization are held in indivisible reserves, and some successful co-operative experiments, such as the Spanish Mondragon group of worker co-operatives, leave open the possibility to develop further models of co-operative finance at least partly based on common ownership (Henrÿ, 2012; cfr. Jossa and Cuomo, 1997; Jossa 2014 on models of externally financed worker co-operatives under public ownership). The exact nature of property rights as concerns: (i) their legal definition as public; socialized (as in the former Yugoslav system); co-operative (as in some European countries); or private (as in common law countries); (ii) the structure of reserves in terms of reimbursement rights; residual rights on the firm's assets; the possibility to reduce reserves following negative economic results; (iii) the balance between individualized and common ownership, all appear to be key elements of sustainable capital accumulation, the overcoming of

${ }^{12}$ In Italy, demutualization of co-operative enterprises is allowed by law only following their renouncing the whole value of indivisible reserves. This value needs to be paid out by the demutualizing co-operative to national and regional funds financing co-operative start-ups. 
undercapitalization; and the prevention of demutualization (Henrÿ, 2012). In the reminder of this section, some initial systematization of the forces at stake in this process of institutional development is carried out.

\subsubsection{The emergence of common capital resources}

The foregoing arguments can be better systematized by analysing the economic forces which favour the emergence of an optimal amount of indivisible capital reserves. These forces need to underpin the stability of accumulated capital and of entrepreneurial processes, without renouncing financial incentives to invest optimally and increase productivity. In this, it should be noted, in the most notable and competitive examples of co-operative and employee owned enterprises, mixed forms of capital ownership are found. Individualized, non-divided, and mixed forms can be singled out in specific cases. In the Mondragon group in the Basque region of Spain, non-divisible reserves of capital coexist with large shares of capital held directly by members in internal capital accounts (Ellerman, 1986, 2007). In the John Lewis Partnership in the UK employees' appropriation rights are strictly regulated and limited by the patrimony capital being held in trust funds, which cannot be shared among members at any time, but which entitles incumbent employees to annual dividends. In many employee owned companies, not all the patrimony is held in trust, and the presence of both individually owned shares and of trust funds is common (Erdal, 2011). This evidence suggests that capital in such ownership forms can be decomposed into different parts, which contribute in different ways to the financial health of the firm. The different parts have different functions: while non-divided ownership is mainly geared to guarantee stable and reliable investment processes and to build collateral guarantees, individual ownership improves financial incentives and performance.

In a new-institutionalist perspective it is necessary to ask what are the costs attached to the transactions involved in each of the two forms of ownership, and their optimal dimension thereof. As already anticipated, individual financial instruments are characterized by high costs connected to members' turnover, which in turn depend on members' different temporal horizons of permanence as incumbent members and on heterogeneous members' objectives. When members show homogeneous temporal horizons and preferences, transaction costs connected with membership and with individual financial positions are low since homogeneity simplifies and lowers the costs of collective decision making, this way limiting conflict and turnover. These elements favour the continuation of the dominance of individual ownership. The well-kwon examples of professional partnerships and of the group of worker owned plywood co-operatives in the US Pacific Northwest in the 20th century share the presence of a highly homogeneous membership performing similar professional and work tasks and having similar educational levels (Craig and Pencavel, 1992, 1994; Hansmann, 1996; Pencavel, 2001; Dow, 1996, 2003). In such cases, non-divided ownership is usually not observed since owned capital and organizational processes can be relatively stable and members would aim at maximizing financial incentives by means of individual ownership (Dow, 1996, 2003). In the framework presented in this paper, members' homogeneous preferences imply that rivalry in utilization of capital resources and non-excludability in collective decision making can be more easily managed. Since the tasks performed by different members are similar, the number of different ends to which capital can be put to use is limited and rules governing utilization of resources and the 
equitable sharing of the surplus are more easily devised and implemented. As complexity and dimension increase, homogeneity fades away, members' objectives become heterogeneous and more difficult to reconcile, this way fostering both organizational and financial instability (Hansmann, 1996). Different preferences concerning investment processes, organizational models and distributive patterns, and different temporal horizons make collective decision making less straightforward and more costly, this way increasing governance costs, members' turnover and the risk of demutualization.

Insofar as it forces the organization to internalize and control, by means of administrative procedures, the costs engendered by individual ownership, non-divided ownership represents one possible remedy, which can give back stability to the financial structure of mutual-benefit organizations, even in the presence of complexity and heterogeneity of preferences. However, non-divided ownership can engender costs and inefficiencies of its own.

One classical problem concerning non-divided ownership has to do with underinvestment due to members' truncated temporal horizon, which arises when the median member is characterized by less than optimal (too short) time horizon for investment programs. This problem is common especially in worker co-operatives due to high members' turnover and median age. It engenders lower than optimal investment schedules and higher then optimal distribution of income and dividends to members, this way leading to under-capitalization (Futubotn and Pejovich, 1970; Vanek, 1970, 1977; Furubotn, 1976; Pérotin, 2013). Under-capitalization is also expected to be more pronounced in declining and low value added sectors of activity, leading to the disappearance of co-operatives in such contexts. Under-capitalization can be effectively counteracted, even in the presence of nondivided ownership, in at least three cases: (i) when the temporal horizon of the median member is sufficiently long and new younger members are constantly associated to the co-operative; (ii) when ownership is mixed and individual shares of capital are found side by side to common ownership, since in this case individual shares would finance the short term component of capital (Tortia, 2007; Pérotin, 2013); (iii) when members' and/or directors' decisions are informed by social preferences that weigh positively the welfare of future generations of members. In this last case, optimal investment schedules are the result of intergenerational solidarity or of positive reciprocity by the incumbent generation of members towards previous generations who handed over the existing stock of capital (Borzaga and Tortia, 2017).

Non-divided ownership can represent an effective institutional device substituting individual ownership only if the new emerging costs of governance are properly controlled through governance, working rules and managerial decisions. In an evolutionary interpretation, common ownership represents an emergent feature of collective action that overcomes individual ownership and the attached contractual costs in the presence of complex and heterogeneous members' objectives (Sacchetti and Tortia, 2015). In more general terms, the interpretation of entrepreneurial action as 
exclusively attached to and explained by individual objectives and behaviour is overcome in favour of collective action (Connell, 1999; Spear, 2012; Vieta, Tarhan and Duguid, 2016) ${ }^{13}$.

\subsubsection{The optimal amount of non-divided capital resources in co-operative enterprises}

The costs and inefficiencies that are likely to be attached to the governance of common capital resources, which derive from the spread of conflict over appropriation and from opportunistic behaviours, are clearly evidenced in the literature concerning "the tragedy of the commons" (Hardin, 1968). They can be high in the absence of adequate regulation (Ostrom, 1990), and this implies that the advantages deriving from common ownership need to be compared with its costs, and with the corresponding costs and benefits attached to individual ownership.

The comparison of costs and benefits is complex as it requires analysis of transactional, operational, and welfare generating or depleting dimensions. However, it offers a vantage point from which empirical research can depart. On the costs side, the equilibrium between common and individual ownership derives from the balance between two categories of net costs attached to the two different ownership regimes: ${ }^{14}$

(i) Costs deriving from the governance of common resources, plus efficiency losses in terms suboptimal investment decisions (horizon problem) and absence of highly powered financial incentives. Costs of governance include lengthy and inconsistent decision making processes, conflict over rules governing exploitation of resources and distribution of proceedings, inefficient choices which privilege the median voter preferences over average preferences;

(ii) Costs deriving from contractual imperfections attached to individual ownership, which can engender organizational impasse, higher turnover and de-mutualization. They derive from conflict over strategic decisions concerning alternative investment plans and their temporal horizon, resource allocation and utilization, and appropriation of proceedings.

Governance becomes the crucial organizational dimension regulating the internalization of contractual costs and their transformation into governance costs (Ostrom, 2009; Ostrom, Janssen and Anderies, 2007). It also bears relevant implications on the alignment of members' objectives with organizational objectives, as the non-divisibility and the non-saleability of common assets not only has empowering effects on collective action, but it also implies the presence of reconstitutive downward effects that tend to modify and refine individual preferences and objectives to make them compatible with collective ones ${ }^{15}$.

\footnotetext{
${ }^{13}$ A non-reductionist interpretation of collective action and institutions as emergent social dimensions, which cannot be explained in terms of individual behaviour alone, but are nonetheless anchored to individual behaviour, is found in prominent contributions to institutional and evolutionary economics (Ostrom, 1990; Hodgson, 1993, 2006).

${ }^{14}$ A detailed comparison of the benefits attached to different ownership forms is outside the scope of this paper, which is limited to the cost side.

${ }^{15}$ On the concepts of reconstitutive downward causation and reconstitutive downward effects, cfr. Hodgson (2011).
} 


\section{The governance of common-pool capital resources}

The previous section concentrated on the economics of non-divided capital resources and on the reasons for their emergence in co-operative enterprises. This section concentrates on their governance. In this, a long tradition in new-institutionalist theory is exploited (Ostrom, 1990; Hansmann, 1996; Williamson, 2000). Oliver Williamson (2000) evidences that ownership rights, insofar as they govern control over capital resources and distribution of the stream of proceedings, are strictly interconnected with governance. While control rights represent the deepest institutional layer in any organizational setting, governance identifies the structure of rules, both externally imposed by law and internally self-produced, that allow the utilization of resources and the implementation of the production process. Different control rights influence governance in different ways: while in IOFs governance is functional to shareholder value maximization, in co-operatives it is functional to members' welfare improvement.

Beyond the legally formalized side of governance, this work mainly addresses forms of selfregulation, which develop through the issuing of bylaws and working rules at the organization level. Working rules embody the modalities by which organizations arrange coordination between the involved actors and prevent deviant behaviours. They can be both enabling and constraining as spelled out in the original definition of institutional economics by John Commons (1931). The literature on common-pool natural resources evidenced that their governance, as examined in a long list of cases worldwide, is based on control and conflict resolution mechanisms, which aim at the correct exploitation and regeneration of the resource in the presence of tragedy of the commons-type dilemmas (Ostrom, 1990; Ratner et al., 2010; Meinzen-Dick, Mwangi and Dohrn, 2006; Poteete, Janssen and Ostrom, 2010). More specifically, the conditions that allow the exploitation of CPRs characterized by scarcity, rivalry in utilization, and non-excludability have been related to three principal conditions: (i) the possibility for the utilizers of the common resource to participate in the gathering activity, and obtain its fruits; (ii) prevention and resolution of conflict; (iii) control of users' behaviour and punishment of violations of collectively defined rules and decisions. This general framework can be reinterpreted and applied in some of its fundamental elements to the case of cooperative enterprises, when these are interpreted as collective entrepreneurial ventures which accumulate and use non-divided capital resources characterized by a high degree of rivalry and nonexcludability.

\subsection{The governance of common capital resources in co-operative firms}

If a comparison is drawn between the exploitation of CPRs and the utilization of non-divided capital resources in co-operatives enterprises, it is possible to observe important similarities in institutional patterns, especially in governance, in terms of rule development and enforcement mechanisms. Members have the right to decide about the pace of accumulation and the modalities of utilization of common resources, which are unavoidably rival in their utilization.

Accumulation, use and distribution of proceedings deriving from the utilization of common resources are strictly connected since, in most cases, new resources are used to substitute the outdated and worn- 
out ones, and reproduce the rivalry of past patterns of utilization and distribution. Different investment plans can engender distributive patterns that favour specific groups of members more than others. The accumulation of common resources in democratically managed, membership based organizations can lead to conflict more easily than in the case of concentrated ownership in IOFs, since different groups of members can prefer different investment plans on the basis of the differential stream of benefits accruing to each group. Utilization is itself liable to conflict for similar reasons: access to a given stock of resources can be regulated in different ways and favour the objectives of specific groups of members more than others. Finally, conflict over the distribution of proceedings generated by common capital resources can be heightened by non-excludability in decision making induced by democratic membership, since all members share the same rights to access and share proceedings, but different regulation concerning how critical decisions are taken can create different patterns of income generation and distribution.

Rivalry and non-excludability in the utilization of common resources in co-operatives create a complex two way process characterized by polarized forces serving different functions. Equal rights, which are functional to implementing bottom-up organizational processes delivering fair procedures and outcomes, are matched by centralized governance, which instead serves, as a norm, the strategic objectives of the organization, which include performance and remuneration on the basis of desert. For example, in worker co-operatives, equal membership rights induce, as a norm, highly egalitarian patterns of resource utilization, professional growth and distribution of proceedings. However, centralized governance would often direct investment plans and resource utilization towards the creation and acquisition of more demanded skills and competences that foster performance, engendering, this way, unequal distributive patterns, since better skills and competence need to be better rewarded to eschew the risk of quittance of best performing workers.

Given the high degree of non-excludability in decision making processes, their regulation becomes critical also to prevent the insurgence of opportunism (Olson, 1965). Opportunistic behaviour can take different forms, some of which are common to most organizational forms, while others are specific to co-operative enterprises. In the former category fall shirking (sub optimal delivery of job effort) in worker co-operatives ${ }^{16}$; the delivery of low quality inputs in agricultural and other producer co-operatives; or the production and circulation of insufficient or distorted information in banking co-operatives. Graduated punishment of defectors may be necessary as means of last resort to deter and counteract opportunism (Ostrom and Basurto, 2011). However, peer pressure, fair procedures and members' involvement, especially when their development is guided by intrinsic, more than extrinsic, motivations, can often represent devices sufficient to marginalize the recourse to sanctions (Stiglitz, 1990; Berger and Udell, 2002).

${ }^{16}$ In IOFs the instruments used to counteract workers' shirking and free-riding usually range from dismissal, to heightened hierarchical control, to the payment of higher than equilibrium efficiency wages and other monetary incentives (Shapiro and Stiglitz, 1984). In worker co-operatives, instead, shirking is more often counteracted by horizontal monitoring (peer pressure), involvement in decision making and by the implementation of fair procedures and distributive patterns (Borzaga and Tortia, 2017). 
In the latter category, excessive or distorted exploitation of capital resources can be included. Excessive exploitation of capital corresponds to overgrazing in a tragedy of the commons situation, and is obtained when the private, not the social, cost of its utilization equals the additional revenue generated by the resource. Members' may be induced to overuse the capital stock, since the costs of utilization and depletion are borne by all members collectively, while individual benefit attached to depletion can be higher than the cost. Distorted utilization can arise when the dominant group or coalitions of members (the ones holding majority votes), administrators or managers divert the utilization of resources towards private objectives aiming, for example, at generating larger income streams in their favour, or at obtaining privileged working conditions. Distorted utilization of resources in co-operatives follows, as a norm, different patterns relative to IOFs since, in the former case, it can arise from lobbying and positional power held by specific groups of members, while in IOFs it is more likely to depend on top-down, exclusive decisions taken by a restricted group of owners (Sacchetti, 2013).

Regulation recognising the specific features and risks attached to co-operative governance is needed to prevent and counteract misbehaviour. In this, procedural and distributive fairness criteria have been evidenced to play a critical role in the absence of centralized decisions taken by fiat. Indeed, third sector organizations, and especially co-operative enterprises, appear to be equipped with particularly high standards of procedural and distributive fairness (Benz and Stutzer, 2003; Tortia, 2008; Valentinov, Hielscher and Pies, 2015).

\subsection{Self-production of rules as general solution to governance failure}

A continuous process of self-production of rules is considered essential to stabilize expectations and reduce conflict as organizational complexity increases since members in a co-operative enterprises are, as a norm, in the best position to work out rules forestalling conflict and opportunism, given their better availability of information, and the accumulated experience concerning the features of the production process and sector of operation (Ostrom, 1990; Gutiérrez, Hilborn and Defeo, 2011; Ostrom and Basurto, 2011).

The process of elaboration of self-defined rules, and of punishment mechanisms in prisoners' dilemma situations, such as public goods production and the tragedy of the commons, came under close scrutiny also in the experimental literature. Peer pressure and punishment of defectors appear to be prominent and closely intertwined with the evolution of social preferences and institutions, since the violation of positive reciprocity expectations in collective action engenders punitive reactions (Fehr, Gächter and Kirchsteiger, 1997; Fehr and Gächter, 2000b, 2002). These general contributions match philosophical interpretations of co-operative enterprises evidencing the founding relevance of reciprocity (Zamagni, 2005), and theoretical contributions dealing with effort provision as a form of reciprocal gift in worker co-operatives (McCain, 2007). Empirical evidence coming both from case studies on the governance of CPRs (Ostrom, 1990) and from the experimental literature on public goods games (Fehr and Gächter, 2000a) is concordant on the relevance of graduated punishment, which is observed to grow more severe as the seriousness of the offence increases. The peers' 
disapproval is translated into explicit or implicit punishment. Explicit punishment can take several forms, ranging from fines, to reduced remuneration and career prospects, to formal exclusion. Implicit punishment can be detected in informal exclusion and marginalization.

The foregoing arguments show the strong similarities existing between the management and exploitation of CPRs, on the one hand, and the accumulation and use of non-divided and non-divisible capital resources in co-operative enterprises, on the other hand. Differences, however, should not be forgotten as well, as they engender important differences in governance rules as well. While the exploitation of natural resources results in final consumption or in saleable production by appropriators, governance of the utilization of capital in entrepreneurial organizations needs to fulfil more complex objectives, for example not only income maximization, but also job stability especially in worker co-operatives (Burdín and Dean, 2012). It represents not a simple input, but the result of complex investments processes, which require planning and lengthy decision making processes. In this, common capital resources and the self-defined rules governing their utilization can represent an empowering, not a limiting factor.

The entrepreneurial and mutual benefit nature of co-operatives increases behavioural, institutional, and organizational complexity relative to other entrepreneurial forms (Cheney et al., 2014). The recognition of the rival and non-excludable nature of the resources used represents a necessary premise to the working out of effective regulation since, for example, the features of the technologies used need to be coherent with collective decision making, and with the widest possible access to material and immaterial capital by the whole membership. Wider access and involvement are expected, in turn, to reduce conflict, opportunism, and the need for punishment (Bowles and Gintis, 1993,1998). Increased coherence between the ability of resources to satisfy individual and collective needs, and decision making processes informed by members' involvement can result in increased productive capacity and productivity. As said, studies show that co-operative governance requires and guarantees high standards of procedural and distributive fairness, and that fairness is strongly associated with members' wellbeing (Benz, 2005; Tortia, 2008). Given the increased complexity in organizational dynamics relative to the case of natural resources and to other entrepreneurial forms, intensive research is needed to support the development of co-operative governance in the presence of non-divided capital resources.

\section{Concluding remarks}

This work represents a first attempt to reformulate the problem of the ownership of capital in cooperative enterprises by analysing it in a new perspective, which looks at how common or nondivided capital resources can bear productive and welfare increasing potential, and not necessarily represent, when properly regulated, an anomaly in or obstacle to the working of entrepreneurial organizations. This new viewpoint can allow taking some steps towards overcoming well-known negative results, such as the ones concerning under-investment and under-capitalization. 
In this, the paper has had two main objectives: (i) to explain, within the new-institutionalist approach, the pattern of emergence and spread (both spontaneous and legally constrained) of non-divided reserves of capital, interpreted as subtractible and non-excludable assets, and to identify the main economic forces defining their optimal level thereof. The answer has been found in the complex comparison between the transactional operational costs attached to individualized vis à vis common reserves of capital; (ii) to offer an initial analysis of the correspondence between the presence of indivisible reserves of capital and the main features of participative and democratic governance in co-operatives. It has been stressed that common resources, when tragedy of the commons-like social dilemmas are overcome, can represent a fundamental and empowering tool allowing members to achieve higher welfare, both monetary and non-monetary, and to fulfil their expectations. Social dilemmas need to be faced by flexible governance solutions which use involvement and fair organizational patterns to prevent lack of commitment, and peer pressure and sanctions to forestall opportunism. As already evidenced in the literature analysing collective governance of CPRs, members and their representatives are in the best position to work out the most effective governance solutions. While the paper focuses on the similarities between the governance of CPRs and the governance of non-divided capital ownership in co-operatives, differences should not be forgotten as well on the way to its implementation, since they can help identifying critical institutional elements, and welfare increasing dimensions that are absent in the former case.

\section{References}

Bartlett, W., Cable, J., Estrin, S., Jones, D.C. \& Smith, S.C. (1992). Labor-Managed Co-operatives and Private Firms in North-Central Italy: An Empirical Comparison, Industrial and Labor Relations Review, 46(1): 103-118.

Battilani, P., Balnave, N. and Patmore, G. (2015). Consumer Co-operatives in Australia and Italy, in A. Jensen, G. Patmore and E.C. Tortia (eds.), Co-operative Enterprises in Australia and Italy. Comparative Analysis and Theoretical Insights, Florence: Firenze University Press, pp. 57-74.

Benz, M. (2005). Not for the Profit, but for the Satisfaction? Evidence on Worker Well-Being in Non-Profit Firms, Kyklos 58(2):155-176.

Benz, M. \& Stutzer, A. (2003). Do workers enjoy procedural utility?, Applied Economics Quarterly, 49(2): 149-172.

Berle, A.A. \& Means, G.C. (1932). The Modern Corporation and Private Property, New York: Mac-Millan.

Birchall, J. (2010). People-Centred Businesses: Co-operatives, Mutuals and the Idea of Membership, London: Palgrave.

Berger, A.N. \& Udell, G.F. (2002). Small Business Credit Availability and Relationship Lending: The Importance of Bank Organizational Structure, The Economic Journal, 112(477): F32-F53.

Blair, M.M. \& Stout, L.A (1999). Team Production Theory of Corporate Law, Virginia Law Review, 85(2): 247-331.

Bonin, J.P., Jones, D.C. \& Putterman, L. (1993). Theoretical and empirical studies of producer co-operatives: will ever the twain meet?, Journal of Economic Literature, 31(3): 1290-1320. 
Borzaga, C. \& Tortia, E.C. (forthcoming in 2017). Co-operation as Coordination Mechanism: a New Approach to the Economics of Co-operative Enterprises, in J. Michie, J. Blasi and C. Borzaga (eds.), The Handbook of Co-operative and Mutual Business, Oxford: Oxford University Press, pp 55-75.

Bowles, S. \& Gintis, H. (1993). A political and economic case for the democratic enterprise, Economics and Philosophy, 9: 75- 100.

Bowles, S. \& Gintis, H. (1998). Mutual monitoring in teams: the effects of residual claimancy and reciprocity. No. 98-08-074e. Santa Fe Institute.

Burdín, G. (2015). Are Worker-Managed Firms more Likely to Fail than Conventional Enterprises? Evidence from Uruguay, Industrial and Labor Relations Review, 46(1): 103-118.

Burdín, G. \& Dean, A. (2012). Revisiting the objectives of worker-managed firms: An empirical assessment, Economic Systems, 36: 158-171

Cheney, G., Santa Cruz, I., Peredo, A.M. \& Nazareno, E. (2014). Worker Co-operatives as an Organizational Alternative: Challenges, Achievements and Promise in Business Governance and Ownership, Organization, 21(5): 591-603.

Cole, H.C., Epstein, G. \& Mcginnis, M.D. (2014). Digging deeper into Hardin's pasture: the complex institutional structure of 'the tragedy of the commons', Journal of Institutional Economics, 10(3): 353369.

Commons, J.R. (1931). Institutional Economics, American Economic Review, 21(3): 648-657.

Connell, D. (1999). Collective Entrepreneurship: In Search of Meaning. University of Northern British Columbia. University of Northern British Columbia, School of Environmental Planning. [Online] Available at: http://www.djconnell.ca/articles/CollEntrep.pdf [Accessed 17 October 2016]

Craig, B. \& Pencavel, J. (1992). The Behavior of Worker Co-operatives, the Plywood Companies of the Pacific North-East, The American Economic Review, 82(5): 1083-1105.

Craig, B. \& Pencavel, J. (1994). The Empirical Performance of Orthodox Models of the Firm: Conventional Firms and Worker Co-operatives, The Journal of Political Economy, 102(4): 718-44.

Deakin, S. \& Hughes, A. (1999). Economic efficiency and the proceduralisation of company law, Company, Financial and Insolvency Law Review, 3: 169-189.

Deakin, S. (2012). The corporation as commons: rethinking property rights, governance and sustainability in the business enterprise, Queen's Law Journal, 37: 339-381.

Dow, G.K. (1996). Replicating Walrasian Equilibria Using Markets for Membership in Labor Managed Firms, Economic Design 2(1): 147-162.

Dow, G.K. (2003). Governing the Firm. Workers' Control in Theory and Practice, Cambridge, MA: Cambridge University Press.

Ellerman, D. (1986). Horizon Problems and Property Rights in Labor-Managed Firms, Journal of Comparative Economics, 10(1): 62-78.

Ellerman, D. (2007). On the Role of Capital in "Capitalist" and in Labor-Managed Firms, Review of Radical Political Economics, 39(1): 5-26.

Erdal, D. (2011). Beyond the Corporation: Humanity Working, London: The Bodley Head.

Euricse (2010). Study on the Implementation of the Regulation 1435/2003 on the Statute for European Cooperative Society ( $S C E$ ), Trento, European Research Institute on Co-operative and Social Enterprises. [Online] Available at:

http://www.euricse.eu/sites/euricse.eu/files/db_uploads/documents/1287749339_n1334.pdf [Accessed 22 February 2016]

Fehr, E. \& Gächter, S. (2000a). Cooperation and Punishment in Public Goods Experiments, The American Economic Review, 90(4): 980-994. 
Fehr, E. \& Gächter, S. (2000b). Fairness and Retaliation: The Economics of Reciprocity, The Journal of Economic Perspectives, 14(3): 159-181.

Fehr, E. \& Gächter, S. (2002). Altruistic Punishment in Humans, Nature, 415(6868): 137-140.

Fehr, E., Gächter, S. \& Kirchsteiger, G. (1997). Reciprocity as a Contract Enforcement Device: Experimental Evidence, Econometrica, 65(4): 833-860.

Frischmann, B.M. (2013). Two Enduring lessons from Elinor Ostrom, Journal of Institutional Economics, 9(4), (Elinor Ostrom memorial issue): 387-406.

Furubotn, E.G. (1976). The Long Run Analysis of the Labour-Managed Firm: An Alternative Interpretation, The American Economic Review, 66(1): 104-123.

Furubotn, E.G. \& Pejovich, S. (1970). Property Rights and the Behaviour of the Firm in a Socialist State: The Example of Yugoslavia, Zeitschrift für Nationalökonomie, 30(5): 431-454.

Gutiérrez, N.L., Hilborn, R. \& Defeo, O. (2011). Leadership, Social Capital and Incentives Promote Successful Fisheries, Nature, 470(7334): 386-389.

Hansmann, H. (1988). Ownership of the firm, Journal of Law, Economics and Organisation, 4(2): 267-304.

Hansmann, H. (1996). The Ownership of Enterpris,. Cambridge, MA: The Belknap Press of Harvard University Press.

Hansmann, H. (1999). Co-operative Firms in Theory and Practice, The Finnish Journal of Business Economics, 4: 387-403.

Hansmann, H. (2001). A Reform Agenda for the Law of Nonprofit Organizations, in K. Hopt and D. Reuter (eds.), Stiftungsrecht in Europa, Hamburg: Carl Heymanns Verlag, pp. 241-272.

Hansmann, H. (2013). All firms are Co-operative, and So Are Governments, JEOD, Journal of Entrepreneurial and Organizational Diversity, 2(2): 1-10. [Online] Available at: http://www.euricse.eu/wp-content/uploads/2016/06/jeodhansmannallfirmsarecooperatives.pdf [Accessed 24 January 2017].

Hardin, G.M. (1968). The tragedy of the commons, Science, 162(3859): 1243-1248.

Henrÿ, H. (2012). Guidelines for Co-operative Legislation. Third edition, Geneva: International Labour Organization.

Hodgson, G.M. (1993). Economics and Evolution: Bringing Life Back into Economic. Cambridge: Polity Press.

Hodgson, G.M. (2006). Economics in the Shadows of Darwin and Marx: Essays on Institutional and Evolutionary Themes, Cheltenham: Edward Elgar.

Hodgson, G.M. (2011). Downward Causation - Some Second Thoughts, Geoffrey Hodgson's website. [Online] Available at: http://www.geoffrey-hodgson.info/downward-causation.htm [Accessed 30 January 2017].

Hodgson, G.M. (2013). Editorial Introduction to the Elinor Ostrom Memorial Issue, Journal of Institutional Economics, 9(4), (Elinor Ostrom memorial issue): 381-385.

Jossa, B. \& Cuomo, G. (1997). The Economic Theory of Socialism and the Labour-managed Firm, Cheltenham: Edward Elgar.

Jossa, B. (2014). A System of Cooperative Firm as a New Mode of Production, London: Routledge.

Lichtenstein, P.M. (1986), The concept of the firm in the economic theory of "alternative" organizations: Appraisal and reformulation. In: S. Jansson \& A.B. Hellmark (Eds.), Labor- owned firms and workers' cooperatives. Gower: Ashgate, pp. 51-72.

Lopes, H., Santos, A.C. \& Teles, N. (2009). The Motives for Cooperation in Work Organizations, Journal of Institutional Economics, 5(3):315-338. 
MCC (2015). Mondragon Annual Report 2015. Mondragon: MCC Corporation. [Online] Available at: http://www.mondragon-corporation.com/eng/about-us/economic-and-financial-indicators/annualreport/ [Accessed 21 January 2017]

McCain, R.A. (2007). Cooperation and Effort, Reciprocity and Mutual Supervision in Worker Co-operatives, Advances in the Economic Analysis of Participatory and Labor Managed Firms, 10: 185-203.

Meinzen-Dick R., Mwangi, E. \& Dohrn, S. (2006). Securing the Common, CAPRi Policy Brief, no. 4, May, $1-3$.

Navarra, C. (2011). Profit Reinvestment in Italian Worker Co-operatives as a Contribution to a Common Good: An Empirical Analysis on Workers' Perception and Motivation, Advances in the Economic Analysis of Participatory and Labor-Managed Firms, 12: 199-229.

Olson, M. (1965). The Logic of Collective Action, Cambridge, MA: Harvard University Press.

Ostrom, E. (1990). Governing the Commons. The Evolution of Institutions for Collective Action, Cambridge: Cambridge University Press.

Ostrom, E. (2007). Challenges and Growth: the Development of the Interdisciplanary Field of Institutional Analysis, Journal of Institutional Economics, 3(3): 239-264.

Ostrom, E. (2009). Social-Ecological Systems. A General Framework for Analyzing Sustainability of SocialEcological Systems, Science, 325(5939): 419-422.

Ostrom, E. (2010). The Challenge of Common-Pool resources, Environment: Science and Policy for Sustainable Development, 50(4): 8-21.

Ostrom, E. and Basurto, X. (2011). Crafting Analytical Tools to Study Institutional Change, Journal of Institutional Economics, 7(3): 317-343.

Ostrom, E., Janssen, M.A and Anderies, J.M. (2007). Going Beyond Panaceas, PNAS, Proceedings of the National Academy of Science, 104(39): 15176-15178.

Pencavel, J. (2001). Worker Participation: Lessons from the Worker Co-ops of the Pacific Northwest, New York, NY: Russel Sage.

Pennington, M. (2013). Elinor Ostrom and the Robust Political Economy of Common-Pool Resources, Journal of Institutional Economics, 9(4), (Elinor Ostrom Memorial Issue): 449-468.

Perilleux, A. (2017). Understanding Cooperative Finance as a New Common, Annals of Public and Cooperative Economics, in press.

Pérotin, V. (2013). Worker Co-operatives: Good, Sustainable Jobs in the Community, Journal of Entrepreneurial and Organizational Diversity. 2(2): 34-47. [Online] Available at: http://www.euricse.eu/wp-content/uploads/2016/06/perotinultimo.pdf [Accessed 22 February 2016].

Podivinsky, J.M. \& Stewart, G. (2006). Why is Labour-Managed Firm Entry so Rare? An Analysis of UK Manufacturing Data, Journal of Economic Behavior and Organization, 56(2): 239-262.

Poteete, A.R., Janssen, M.A \& Ostrom, E. (2010). Working Together: Collective Action, the Commons, and Multiple Methods in Practice, Princeton, NJ: Princeton University Press.

Ratner, B.D., Meinzen-Dick, R., May, C. \& Haglund, E. (2010). Resource Conflict, Collective Action, and Resilience. Washington DC, CAPRi Working Paper no. 100. [Online] Available at: http://ebrary.ifpri.org/cdm/singleitem/collection/p15738coll2/id/7395 [Accessed 22 February 2016].

Sacchetti, S. (2013). Inclusive and Exclusive Social Preferences: a Deweyian Framework to Explain Governance Heterogeneity, Journal of Business Ethics, 126(3): 473-485.

Sacchetti, S. \& Campbell, C. (2014). Social Enterprise Networks and Social Capital: A Case Study in Scotland, in A. Christoforou and J. B. Davis (eds.), Social Capital and Economics: Social Values, Power, and Social Identity. London: Routledge, pp. 215-235.

Sacchetti, S. \& Tortia, E.C. (2015). The Silver Lining of Co-operation. Self-defined Rules, Common Resources, Motivations, and Incentives in Co-operative Firms, in A. Jensen, G. Patmore and E.C. Tortia 
(eds.), Co-operative Enterprises in Australia and Italy. Comparative analysis and theoretical insights, Firenze: Firenze University Press, pp. 175-190.

Sacconi, L. (2004). Corporate Social Responsibility (CSR) as a Model of "Extended" Corporate Governance. An Explanation Based on the Economic Theories of Social Contract, Reputation, and Reciprocal Conformism, LIUC University. LIUC Papers no. 142. [Online] Available at: http://www.biblio.liuc.it/liucpap/pdf/142.pdf [Accessed February 9 2017]

Sacconi, L. \& Ottone, S. (2015) (eds.). Beni Comuni e Cooperazione, Bologna: Il Mulino.

Shapiro, C. \& Stiglitz, J.E. (1984). Equilibrium Unemployment as a Worker Discipline Device, The American Economic Review, 74(3): 433-444.

Spear, R. (2012). Innovation and Collective Entrepreneurship, Universitas Forum: International Journal on Human Development and International Cooperation, 3(2): 1-15. [Online] Available at: http://oro.open.ac.uk/2536/1/123-807-1-PB.pdf [Accessed 17 October 2016].

Stiglitz, J.E. (1990). Peer monitoring and credit markets. World Bank Economic Review, 4(3): 351-366.

Storey, J., Basterretxea, I. \& Salaman, G. (2014). Managing and Resisting 'Degeneration' in Employee Owned Businesses: A Comparative Study of Two Large Retailers in Spain and the United Kingdom, Organization, 21(5): 626-644

Tortia, E.C. (2007). Self-Financing in Labour-Managed Firms: Individual Capital Accounts and Bonds, Advances in the Economics Analysis of Participatory and Labor Managed Firms, 10: 233-261.

Tortia, E.C. (2008). Worker Motivations, Job Satisfaction, and Loyalty in Public and Non-Profit Social Services, The Journal of Socio-Economics, 37(5): 2080-2094.

Valentinov, V. (2015). From equilibrium to autopoiesis: A Luhmannian reading of Veblenian evolutionary economics, Economic Systems, 39: 143-155.

Valentinov, V., Hielscher, S. \& Pies, I. (2015). Nonprofit organizations, institutional economics, and systems thinking, Economic Systems, 39: 491-501.

Vanek, J. (1970). The General Theory of Labour Managed Market Economies, Ithaca, NY: Cornell University Press.

Vanek, J. (1977). The Labor-Managed Economy, Ithaca, NY: Cornell University Press.

Vieta, M.A., Tarhan, M.D. \& Duguid, F. (2016). From Collective to Co-operative Entrepreneurship in Canada's New Co-operatives'. Ontario Institute for Studies in Education, University of Toronto. [Online] Available at: http://ccr.ica.coop/sites/ccr.ica.coop/files/attachments/2.2\%20Vieta_Tarhan_Duguid.pdf [Accessed 17 October 2016]

Williamson, O.E. (2000). The New Institutional Economics: Taking Stock, Looking Ahead, Journal of Economic Literature 38(3): 595-613.

Zamagni, S. (2005). Per una Teoria Civile dell'Impresa Cooperativa, in E. Mazzoli and S. Zamagni (eds.), Verso una Nuova Teoria della Cooperazione. Bologna: Il Mulino, pp. 15-56. 